\title{
EFFECTS OF NEEM OIL ON THE PRESERVATION OF MILICIA EXCELSA: EVALUATION OF TERMITICIDAL EFFECTIVENESS
}

\author{
Ettagbor Hans Enukwa ${ }^{1}$ (iD, Yilom Hyginus Ndang ${ }^{2}$ \\ ${ }^{1}$ Department of Civil Engineering and Forestry Techniques, Higher Technical Teacher Training \\ College, University of Bamenda, P.0 Box 39 Bambili, Cameroon
}

DOI: https://doi.org/10.29121/granthaalayah.v8.i12.2020.2873

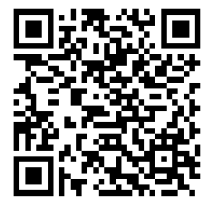

Article Type: Research Article

Article Citation: Ettagbor Hans Enukwa, and Yilom Hyginus Ndang. (2020). EFFECTS OF NEEM OIL ON THE PRESERVATION OF MILICIA

EXCELSA: EVALUATION OF TERMITICIDAL EFFECTIVENESS. International Journal of Research GRANTHAALAYAH, 8(12), 315-322. https://doi.org/10.29121/granthaa layah.v8.i12.2020.2873

Received Date: 14 November 2020

Accepted Date: 31 December 2020

Keywords:

Deterioration

Environmentally Friendly

Preservative

Termites

Weight Loss

\begin{abstract}
Wood usage has increased with time, thus, there is need to investigate how wood can be treated with human and environmentally friendly preservative which is effective in protecting wood from termites and other agents of wood deterioration, or improve the wood physical, chemical, mechanical and biological characteristics. The aim of this study was therefore to evaluate the effects of neem oil on Milicia excelsa wood preservation. Treated and untreated pieces of Milicia excelsa wood samples were used to carry out this experiment, a soil bed, and an internal wood exposure to termite's test was carried out, and measurements taken using a digital weighing machine. The results obtained showed that, when Milicia excelsa is treated with neem oil, its Rate of Decay (ROD) reduces as compared to the untreated pieces. Also, neem oil treated wood when exposed to termite's attack experiences a slower weight loss compared to untreated samples with significant weight loss. Neem oil is thus not only effective in preserving woods, but also non- toxic to human and the environment.
\end{abstract}

\section{INTRODUCTION}

Throughout history, people have relied on wood for varied uses such as housing, furniture, tools, transport, entertainment, learning, and multitude of other products. Wood from time immemorial has been established as a construction material in wood industries for variety of applications such as construction of buildings such as stadia, ships, furniture items, bridges, boats, lorries, tractor wagons and aircraft carrier. Wood is also used in the production of musical instruments such as guitar, piano, violin, tambourines; in tool making such as hammer handles, pick axes, pulp and paper for the production of exercise books, newspapers, magazines; sports wares such as hockey sticks, tennis bats, tennis rackets and cricket bails (Bamiro et al. 1986).

The wide range use of wood, technological advancement, wood deterioration, deforestation and population increase in Cameroon have placed a remarkable rise in demand and use of timber. The demand for timber is rising in every part of the country without a balanced supply to meet this demand. Gradually, durable wood is becoming scarce and expensive particularly in the North West part of Cameroon and therefore there is need to find alternative timber species to supplement the existing economic species commonly in use which include some of the plants

(C) 2020 The Author(s). This is an open access article distributed under the terms of the Creative Commons Attribution License, which permits unrestricted use, distribution, and reproduction in any medium, provided the original author and source are credited. 
introduced during colonial period like Eucalyptus, Callistemon viminalis, globulus and Syzygium staudtii; agroforestry species like Calliandra callothyrsus, Leucaena lleucocephala, and Casuarina equisefolia; the citrus species such as Cupressus benthani and Pinus sylvestris; and the Podocarpus species.

Despite its importance to the wood industries and the end users, there is however the threat of wood degradation brought about by mechanical wear through abrasive action, decomposition caused by physical agencts such as prolonged heating or exposure to weather and chemical decomposition (Goodell et al. 2003). Another common major cause of wood degradation is bio-deterioration which is the action of foreign biological agents such as fungi, insects, bacteria and marine borers. According to Wong and Cheok (2001), wood degradation by termites is a chronic problem in many tropical and even some temperate regions of the world, resulting in serious monetary, material losses and an increasing demand for timber.

Major destructive agents to buildings constructed of sound materials and workmanship are the termites (Wong and Cheok, 2001; Ezeji, 1984). Termites mostly feed on dead plant material, mostly wood, leaf litter, soil, or animal dung. According to Ezeji (1984), termites are insects which live in communities and feed principally on wood substance called cellulose. The cellulose is the structural framework of the primary cell wall of wood which forms $45 \%$ to $50 \%$ of the wood substance. The major types of termites that attack and feed on woods cellulose are identified as the subterranean, damp wood and the dry wood termites (Ezeji, 1984; Jones et al. 2007).

Termites make narrow holes by eating out the timber and the galleries so made provide accommodation for the various members of the colony. As the number of galleries increases, they merge to form large cavities in the timber and the evidence of their infestations can hardly be noticed until they eat up the wood leaving the casing (Ezeji, 1984). Some evidences of wood infestation by termites include weight loss, loss of form and shape, wood easily breaks apart, development of shelter tubes, galleries or tunnels in an irregular pattern, dull sound when tapped and structural weakness. In Cameroon, the subterranean and dry-wood termites have been identified as major cause of wood biodegradation (Femi-Ola \& Aderibigbe, 2008; Ezeji, 1984). Wood degradation by termites and other insects over the years have been inhibited by using naturally resistant wood species and the use of wood preservatives.

Wood preservative is any substance that is effective in preventing the development and action of wood fungi, termites and pests of various kinds within a considerable period of time. Bamiro al. (1986) and Kingsland (2011) enumerated the qualities of a good wood preservative to be: poisonous to the destructive agents but harmless to its operators, easy to handle and apply to wood, odourless, cheap and easily obtainable, chemically stable for a long period, leach and evaporation proof. Wood preservatives are classified into three general classes which are the Oiltype or Oil borne preservatives, such as Creosote, Coal- Tar, Solignum and petroleum solutions of pentachlorophenol; Water borne preservatives such as Chromated Copper Arsenate, Ammoniacal Copper Zinc Arsenate and boron; and the Organic-Solvent preservatives such as Chlorinated phenols and Sodium Pentachlorophenol. These wood preservatives are applied on wood for either interior or exterior wood constructions. The common methods of applying the wood preservatives are brushing and spraying, dipping and soaking, hot and cold tank; and pressure treatment.

Preservatives are applied based on how and where the products will be used, the expected conditions of exposure to wood destroying agents in the ground, above the ground and in marine environment. The length of time over which these chemicals remain effective as stated by Ezeji (1984), depends on a number of factors including the type of soil, exposure to weather and the kind of termite involved.

The effectiveness of wood preservative against termites is established when the preservative treated wood has high resistance to termite's infestation in situations close to the practical usage over a period without losing its efficacy of protecting the wood (Edlund et al. 2006). The question of effectiveness of the highly toxic chemical preservatives to inhibit and destroy wood deteriorating agents and in particular termites is not in doubt but the hazards associated with their use have led to their ban in the United States of America and the 27 European Union countries (European Union Commission, 2001; Dickey, 2003). The ban on the use of creosote, coal-tar, solignum, chromate copper arsenate, ammonical copper arsenate, pentachlorophenol and several others due to the high level of toxicity to the handlers of wood preservatives, residential and non-residential users of treated wood and the environment, has opened up alternative development of low and non-toxic wood preservatives in the EU countries and the US. Some of these new wood preservatives such as alkaline copper quaternary, concentrated borate, copper azole, biguanide, and polyenones are readily available only mostly in the EU countries but very expensive and in most cases unaffordable in non-EU countries (EU Commission, 2001). There is therefore need for the developing countries like Cameroon to look for alternative wood pest control preservatives that are low in toxic content or nontoxic to human beings and the environment (Ohmura et al. 2000; Rodrigues et al. 2012; Syofuna et al. 2012). The 
possibility of getting an effective, environmentally and human friendly wood preservative may be found in organically based sources such as plants and tree extracts; a likely source might be extracts from the neem tree.

The neem tree (Azadirachta Indica A. Juss), is a tropical evergreen tree with wide adaptability and like the Mahogany tree, it is known to be resistant to insect infestation (Giger 2001). Neem is one of the most versatile, multifarious trees of tropics, with immense potentials, and it possesses maximum useful non-wood products (leaves, bark, flowers, fruits, seeds, gum, oil and neem cake) than any other tree species (Girish and Shankara (2008). These non-wood products are known to have anti-allergenic, anti-dermatic, anti-feeding, anti-fungal, anti-inflammatory, anti-pyorrhoeic, anti-scabic, cardiac, diuretic, insecticidal, larvicidal, nematicidal, spermicidal and other biological importance, thus because of these enormous applications, neem has become a green treasure tree in many countries (Giger, 2001; Girish \& Shankara, 2008). Neem oil and extracts have been reported to be active against termites, including Zootermopsis nevadensis (Ohmura et al. 2006), Reticulitermes speratus (Serit et al. 1992), Coptotermes formosanus (Grace and Yates 1992, Doolittle et al. 2007), and Incisitermes marginipennis (Arcos-Roa et al. 2001). In Cameroon, neem tree is now widely grown and thrives well in four of the 10 regions of the country. In the North west region, there is high density of the trees especially in Boyo division part of the region and the seeds are easy to collect from the ground or could be harvested. Neem oil is extracted from the seeds of neem tree which contain $45 \%$ of brown and bitter oil (Hayden, 1998; Giger, 2001). The wide applications of neem extracts provided a window for its oil to be examined if it can be used for wood preservation of predominant timbers in the Northwest region of Cameroon, thus giving the basis for this study. This study is therefore aimed at determining the efficacy of neem oil in its ability to prevent Milicia excelsa wood from termite destruction.

\section{MATERIALS AND METHODS}

\subsection{DESIGN OF STUDY}

The research design employed in the study was Research and Development (R \& D), aimed at developing products and field testing the products to confirm their efficacy before use (Gall et al. 2007). Although costly and demanding, R\&D activities provide valuable means of not only developing new products but improving on existing ones for wider usage and applications. The design was found appropriate for the study since it focused on developing new products or finding alternative applications for a product. Neem oil had been used for different applications and the need to exploit its use for the treatment of Milicia excelsa timber in the Northwest region is considered imperative.

\subsection{STUDY AREA}

This study was conducted in Mezam division, North West region of Cameroon, where Milicia excelsa wood is highly available and frequently used for various wood constructions. This wood specie was found susceptible to termites and other agents of wood degradation (Keay, 1989). It was noticed that in this area, there was high prevalence of termite infestations which led to material loss, loss of property, risk to human lives and the environment.

\subsection{SAMPLE PREPARATION AND COLLECTION}

Materials that were used for the collection of the samples were: measuring rule/ tape, try-square, pencil, ripsaw, cross-cut saw, sack, sensitive digital weighing scale, $25 \mathrm{~mm}$ hand brush and open oil can. The 3 - meter measuring tape was used for measuring length of wood samples cross-cut or ripped. The try-square was used to guide the measuring and marking of the width and short length of wood samples that were cross-cut; the same instrument was used in drawing perpendicular lines to the edge of wood samples. The pencil was used to indicate marks for ripping and cross-cutting of wood samples. The ripsaw was used to cut along the grain of planks following the width line marks while the cross-cut saw was used to cut across the grain of the planks. The jute sack was used to collect the cut wood samples from the timber shade in the area of study and conveyed to the researcher's workshop. The weighing scale was used for pre-weighing and post-weighing the treatment and control wood samples. The $25 \mathrm{~mm}$ hand brush was used to clean the cut samples, while the open Oil Can was used as the receiver of neem oil from the 
Effects of Neem Oil on The Preservation of Milicia Excelsa: Evaluation of Termiticidal Effectiveness

bottle before dipping the wood samples. The sample collection and experiment were carried out in two phases. Sixteen pieces each of Milicia excelsa measuring $30 \mathrm{~mm} \times 50 \mathrm{~mm} \times 150 \mathrm{~mm}$ were cut from defect free part of the timber obtained from timber market in the study area. Eight pieces were randomly selected from the samples of defect free wood samples cut from the timber and used as treatment and eight used as control. This experiment was replicated. The selection of these timbers was based on the fact that Milicia excelsa woods are widely used for various wood/building constructions in the Northwest region and are susceptible to termite infestation. Processed neem oil was purchased from the local market in the Northwest region for the treatment of the experimental samples.

\subsection{EXPERIMENTAL DESIGN}

The wood sample pieces were prepared in accordance with the American Wood Preservers Association (AWPA) E1-97[1999] and Nordic Wood Preservation Council (NWPC) EN252 [2006] standards for the field trial tests. All the wood samples were oven dried to ensure that the moisture content of each is not above $20 \%$. The reduction of the moisture content was to facilitate easier absorption and penetration of the preservative in to the wood samples. All the samples were randomly allotted letters, labeled with the first letter of the wood sample type and either UT or T indicating untreated or treated sample; for example, $A_{T}$ on wood sample meant Sample A Treated or $B_{U}$ meant Sample B Untreated. The labeled wood samples were then randomly selected and grouped into two, treatment and control ( 8 treated and 8 untreated). Each wood sample in the two groups was then weighed for its pre-infestation weight using the digital weighing scale and values of the pre-infestation weights recorded. Eight pieces of wood of the defect free Milicia excelsa sample randomly selected were treated with neem oil by immersing each test sample into the container filled with the oil. This immersion was done twice for each sample within 24 hours to enable penetration and drying of the treated pieces. All the treated samples were then air dried for 72 hours ( 3 days), and weighed to ensure that the absorption of the oil treatment did not significantly affect the pre-test weights of the samples.

Two termite infested locations both exterior and interior were chosen at the Royal furniture Centre area at Mile 4 Nkwen Bamenda. This location was chosen because of its high rate of termite infestation and for the ease of close monitoring for the field test trial of both treated and untreated wood samples. A termite mound for the exterior infested environment was identified and dug to a depth of $15 \mathrm{~cm}$ to ensure contact with termite activity and protect wood samples from curious passersby while the roof trusses of a motor garage infested with termites were used for the interior environment. Eight wood samples comprising of the treated and untreated pieces were randomly installed inside the termite mound and buried while another group of eight treated and untreated wood samples were placed on the plates and beams of the motor garage trusses according to AWPA E1-97 and NWPC EN 252 standards of field testing of the effectiveness of wood preservatives. The placement of the samples in both interior and exterior locations were mapped and recorded in order to assist the researcher to recover the samples with their appropriate labels. The wood samples both treated (experimental) and untreated (control) were allowed for a period of nine weeks between March and May 2020 (a period within which termite infestation is normal), before they were retrieved for weighing and visual rating.

\subsection{DATA COLLECTION}

Data was collected based on field experimental research principles through observation (visual inspection), weighing of samples and recording of values. Pre-infestation weights of wood samples were measured using a sensitive digital weighing scale and the values recorded before exposure of samples to termite infestations. Postinfestation weight of wood samples after nine weeks of infestation were measured and values also recorded. Data on the extent of infestation and deterioration of wood samples for the study were based on a 5- point visual inspection rating adopted from the American Society for Testing and Materials (ASTM), International D1758-06 (2010) standards of rating wood for deterioration. The rating was done after the period of nine weeks of exposure of treated and untreated wood samples to termites. Each of the pieces of wood exposed to termite infestation was observed and rated based on the 5-point ASTM Durability Rating Scale (Table 1). 
Table 1: A 5-Point ASTM Durability Rating Scale. Culled from the International Research Group on Wood Protection (2010).

\begin{tabular}{|c|c|c|}
\hline Visual Rating Scores & Real Limits & Description \\
\hline 10 & $9.6-10$ & Sound Timber, No Termite Attack \\
\hline 9 & $8.1-9.5$ & Trace of Termite Attack \\
\hline 7 & $5.6-8.0$ & Moderate Termite Attack \\
\hline 4 & $2.1-5.5$ & Heavy Termite Attack \\
\hline 0 & $0-2.0$ & Destructive Termite Attack \\
\hline
\end{tabular}

\subsection{DATA ANALYSIS}

Pre-infestation weights of all wood samples were first recorded and then the post infestation weight values after the period of experiment were also taken. Percentages and mean weight losses were calculated from the preinfestation weight and post-infestation weight values to determine the effectiveness of neem oil in preserving the wood samples from wood weight losses as a result of termite infestations. Values from the visual inspection ratings of the wood samples were also noted to arrive at the mean values on the extent of deterioration and this data was analyzed using the mean statistics. T-test analysis was used to compare between means of the untreated and treated samples.

\section{RESULTS AND DISCUSSIONS}

\subsection{ABSORPTION OF NEEM OIL BY IROKO SAMPLES}

From the total quantity of neem oil used for treatment of the experimental samples, it was realized that a large quantity was not absorbed, while some amount of the oil was absorbed (Table 2).

Table 2: Absorption of neem oil by treated iroko wood samples

\begin{tabular}{|c|c|c|c|}
\hline Quantity used $\left(\mathrm{cm}^{3}\right)$ & Quantity not absorbed $\left(\mathrm{cm}^{3}\right)$ & Quantity absorbed $\left(\mathrm{cm}^{3}\right)$ & \% absorbed \\
\hline 1,000 & 842 & 158.5 & 15.9 \\
\hline
\end{tabular}

The table above indicates that when neem oil is effectively applied on iroko wood sample, some of the liquid gets into the wood which is necessary to further enhance the protection of the wood from agents of wood deterioration, especially termites. This finding is in line with that of Olufemi et al. (2007) who reported an absorption rate of over $9.42 \%$ neem oil by Khaya senegalensis when used for its treatment against agents of wood deterioration. Considering that the iroko wood samples used in this study were oven dried so as to reduce the amount of moisture in them, and that neem oil was adequately applied to the samples, these could have contributed to the significant absorption rate recorded.

\subsection{INFLUENCE OF NEEM OIL ON PRESERVATION OF MILICIA EXCELSA}

After the nine weeks experimental period, the final weight of each treated and untreated wood sample was recorded, and this revealed that weight loss for treated samples was relatively lower compared to the untreated samples (Tables 3 \& 4).

Table 3: Weight loss for termite infested Milicia excelsa untreated wood samples

\begin{tabular}{|c|c|c|c|c|}
\hline Sample number & Initial weight (g) & Final weight (g) & Weight loss (g) & \% weight loss \\
\hline 1 & 185 & 138.1 & 46.9 & 25.4 \\
\hline 2 & 185 & 145.2 & 39.8 & 21.5 \\
\hline 3 & 185 & 141 & 44 & 23.8 \\
\hline 4 & 185 & 150.2 & 34.8 & 18.8 \\
\hline 5 & 185 & 149 & 36 & 19.5 \\
\hline
\end{tabular}


Effects of Neem Oil on The Preservation of Milicia Excelsa: Evaluation of Termiticidal Effectiveness

\begin{tabular}{|c|c|c|c|c|}
\hline 6 & 185 & 145.5 & 39.5 & 21.4 \\
\hline 7 & 185 & 147 & 38 & 20.5 \\
\hline 8 & 185 & 149.5 & 35.5 & 19.2 \\
\hline
\end{tabular}

Table 4: Weight loss for treated Milicia excelsa wood samples

\begin{tabular}{|c|c|c|c|c|}
\hline Sample number & Initial weight (g) & Final weight (g) & Weight loss (g) & \% weight loss \\
\hline 1 & 185 & 175.2 & 9.8 & 5.3 \\
\hline 2 & 185 & 179 & 6 & 3.2 \\
\hline 3 & 185 & 177.3 & 7.7 & 4.3 \\
\hline 4 & 185 & 171.3 & 13.7 & 7.4 \\
\hline 5 & 185 & 177.2 & 7.8 & 4.2 \\
\hline 6 & 185 & 175.3 & 9.7 & 5.2 \\
\hline 7 & 185 & 179 & 6 & 3.2 \\
\hline 8 & 185 & 176.5 & 8.5 & 4.6 \\
\hline
\end{tabular}

Similar findings were also reported by Olufemi et al. (2011) which indicated that when wood is treated with neem oil, the rate at which its losses weight with time when exposed to agents of wood deterioration especially termites is relatively lower compared to untreated wood.

\subsection{RATE OF TERMITE ATTACK ON TREATED AND UNTREATED WOOD SAMPLES}

Using the 5-Point ASTM Durability Rating Scale to verify the degree of termite attack on the treated and untreated wood samples, it was realized that untreated wood samples experienced significant destruction by termites compared to wood samples treated with neem oil (Table $5 \& 6$ ).

Table 5: Extent of termite attack on untreated Milicia excelsa wood samples

\begin{tabular}{|c|c|c|c|}
\hline Sample number & Visual rating score & Real limit & Description \\
\hline 1 & 4 & $2.1-5.5$ & Heavy Termite Attack \\
\hline 2 & 4 & $2.1-5.5$ & Heavy Termite Attack \\
\hline 3 & 4 & $2.1-5.5$ & Heavy Termite Attack \\
\hline 4 & 7 & $5.6-8.0$ & Moderate Termite Attack \\
\hline 5 & 7 & $5.6-8.0$ & Moderate Termite Attack \\
\hline 6 & 4 & $2.1-5.5$ & Heavy Termite Attack \\
\hline 7 & 4 & $2.1-5.5$ & Heavy Termite Attack \\
\hline 8 & 7 & $5.6-8.0$ & Moderate Termite Attack \\
\hline
\end{tabular}

Table 6: Extent of timber attack on treated Milicia excelsa wood samples

\begin{tabular}{|c|c|c|c|}
\hline Sample number & Visual rating score & Real limit & Description \\
\hline 1 & 9 & $8.1-9.5$ & Trace of Termite Attack \\
\hline 2 & 9 & $8.1-9.5$ & Trace of Termite Attack \\
\hline 3 & 9 & $8.1-9.5$ & Trace of Termite Attack \\
\hline 4 & 9 & $8.1-9.5$ & Trace of Termite Attack \\
\hline 5 & 9 & $8.1-9.5$ & Trace of Termite Attack \\
\hline 6 & 9 & $8.1-9.5$ & Trace of Termite Attack \\
\hline 7 & 9 & $8.1-9.5$ & Trace of Termite Attack \\
\hline 8 & 9 & $8.1-9.5$ & Trace of Termite Attack \\
\hline
\end{tabular}

The reduction in the extent of termite attack on treated wood samples compared to untreated samples suggest that, neem oil could be effective in limiting the degree of wood destruction. Gilmara et al. (2013) reported a lower rate of termite destruction on neem oil treated than untreated wood samples. The use of neem oil on wood preservation is thus an effective strategy, especially when well applied. To compliment this, well-seasoned neem oil 
treated wood is highly recommended for use as it will be more resistant to deterioration. Owing to the problems associated with wood biodeterioration, especially in tropical countries, treatment techniques using preservatives are imperative if wood is to be used in construction (Cavalcante, 1982).

\section{CONCLUSION}

The nonapplication of wood preservatives on wood makes it wide-open to termite infestation and deterioration. This fact was established in the case of untreated Milicia excelsa wood samples which suffered vast termite attacks as compared to the treated wood samples which had significant levels of resistance to termite infestation. The possibility of using neem oil as a preservative provides a window for its adaptation as an alternative wood preservative that is safe for human handling and to the environment. It can thus be inferred that neem oil has the potential of being an effective wood preservative. It would be necessary to conduct further experiments with a mixture of neem oil and other possible substances to verify the behavior and effectiveness compared to using neem oil alone.

\section{SOURCES OF FUNDING}

This research received no specific grant from any funding agency in the public, commercial, or not-for-profit sectors.

\section{CONFLICT OF INTEREST}

The author have declared that no competing interests exist.

\section{ACKNOWLEDGMENT}

None.

\section{REFERENCES}

[1] Arcos-Roa, J., Mendez-Montiel, J.T. \& Campos-Bolanos, R. (2001). Efecto del aceite de Nim Azadirachta indica a. juss sobre la termita de madera seca Incisitermes marginipennis (Latreille) (Isoptera: Kalotermitidae). Rev. Chapingo 7:139-143.

[2] Bamiro, O.A., Nurudeen, A. \& Akunu, I.O. (1986). Introductory technology for schools and colleges. Ibadan, Nigeria. Evans Brothers Nig. Pub. Ltd.

[3] Cavalcante, M.S. (1982). Biological deterioration and wood preservation. Technological Research Institute, Sao Paulo, 40pp.

[4] Dickey, P. (2003). Guidelines for selecting wood preservatives: San Francisco Department of the Environment. San Francisco, USA. Retrieved from http://www.sfenvironment.org on 20th May, 2011.

[5] Doolittle, M., Raina, A., Laxand, A. \& Boopathy, R. (2007). Effect of natural products on gut endosymbiotic microbes in formosan subterranean termites. Int. Biodeter. Biodegrad. 59:69-71.

[6] Edlund, M.L, Evans, F. \& Henriksen, K (2006). Testing Durability of Treated Wood. NT- Technical Report (591) for Nordic Test Fields. Stensberggata, Norway.

[7] European Union Commission (2001). Revocation of Approvals for Amateur CreosoteCoal tar Wood Preservatives. A Bulletin of Health and Safety Executive No.2001/90/EC,Belgium. Retrievedfrom http://www.hse.gov.uk on 16th June, 2011.

[8] Ezeji, S.C. (1984). Building construction. Harlow, England: Longman Group Limited.

[9] Femi-Ola, T.O. \& Aderibigbe, E.Y. (2008). Studies on the Effect of Some Wood Extracts on Growth and Cellulose Production by Strains of Bacillus Subtili: Asian Journal of Plant Sciences. ISSN 1682-3974.

[10] Gall, M.D., Gall, J.P. \& Borg, W.P. (2007). Educational research: an introduction. 8thEdition. New York, USA: Pearson Education Inc. 
[11] Giger, M. (2001). The Neem Tree: The Village Pharmacy. Retrieved from http://www.aijsc.com on 15th March,2011.

[12] Gilmara, O.M., Laurie, J.C., Andre', L.C., Wagner, L.P., Marcio, R.S., Carlito, C.J. \& Francisco Antonio, R.L. (2013). Wood Preservation Based on Neem Oil: Evaluation of Fungicidal and Termiticidal Effectiveness. Forest Products Journal: 63:202-206.

[13] Girish, K. \& Shankara, B.S. (2008). Neem: A Green Treasure. Karnataka, India. An Electronic Journal of Biology: 4(3):102-111.

[14] Goodell, B., Nicholas, D.D. \& Schultz, T.P. (2003). Introduction to Wood Deterioration and Preservation. American Chemical Soceity Symposium Series. Retrieved from WWW.pubs.acs.org on 20th May, 2011.

[15] Grace, J.K. \& Yates, J.R. (1992). Behavioral effects of a neem insecticide on Coptotermes formosanus (Isoptera: Rhinotermitidae). Trop. Pest Manag. 38:176-180.

[16] Hayden, J. (1998). The Neem Tree and its Uses: A report of observations. Jos, Nigeria.

[17] Jones, S., Kick-Rack, J. \& Pound, W. (2007). Wood- Destroying Insect Diagnostic Inspection. Study Guide for Commercial Application Category 12. Ohio,USA.

[18] Keay, R.W.J. (1989). Trees of Nigeria. New York, U.S.A: Oxford University Press, New York.

[19] Kingsland, L.F. (2011). Wood Preservation. Retrieved from www.pubs.cif-ifc.org on 26th July,2011.

[20] Olufemi A. Sotannde, Gabriel O. Yager, Bamidele D. Zira and Abubakar Usman, 2011. Termiticidal Effect of Neem Extracts on the Wood of Khaya senegalensis. Research Journal of Forestry. 5:128-138.

[21] Rodrigues, A.M., Stien, D., Eparvier, V., Espindola, L.S., Beauche, J., Amusant, N., Leme N., Baudasse, C. \& Raguin, L. (2012). The wood preservative potential of long-lasting Amazonian wood extracts. Int. Biodeter. Biodegrad. 75:146-149.

[22] Serit, M., Ishida, M., Nakata, K., Kim, M. \& Takahashi, S. (1992). Antifeeding potency of neem (Azadirachta indica) extractives and limonoids against termite (Reticulitermes speratus). J. Pestic. Sci. 17:267-273.

[23] Syofuna, A., Banana, A.Y. \& Nakabonge, G. (2012). Efficiency of natural wood extractives as wood preservatives against termite attack. Maderas Cienc. Tecnol. 14(2):155-163.

[24] Wong, A.H.H. \& Cheok, K.S. (2001). Observations of Termite-Fungus Interaction of Potential Significance to Wood Bio-deterioration Protection: TimberTechnology Bulletin No. 24, Timber Technology Centre KualaLumpur. 